\title{
Predictive Capability of HPV and Pap Tests in Screening for Cervical Cancer over a Three-Year Follow-up
}

\section{Capacidade preditiva dos testes HPV e Papanicolau no rastreamento para câncer do colo do útero em três anos de seguimento}

\author{
Vania Reis Girianelli ${ }^{1}$ Luiz Claudio Santos Thuler ${ }^{2,3}$ \\ ${ }^{1}$ Instituto Nacional de Infectologia Evandro Chagas, Fundação \\ Oswaldo Cruz, FIOCRUZ, Rio de Janeiro, RJ, Brazil \\ 2 Universidade Federal do Estado do Rio de Janeiro, UNIRIO, Rio de \\ Janeiro, RJ, Brazil \\ 3 Division of Clinical Research, Instituto Nacional de Câncer - INCA, \\ Rio de Janeiro, RJ, Brazil \\ ${ }^{4}$ Instituto de Medicina Social, Universidade do Estado do Rio de \\ Janeiro, UERJ, Rio de Janeiro, RJ, Brazil
}

\author{
Gulnar Azevedo e Silva ${ }^{4}$
}

Rev Bras Ginecol Obstet 2016;38:147-153.

\begin{abstract}
Address for correspondence Vania Reis Girianelli, PhD, Instituto Nacional de Infectologia Evandro Chagas - Fiocruz, Plataforma de Pesquisa Clínica, Av. Brasil, 4365, Manguinhos, Rio de Janeiro, RJ, Brazil 21040-360 (e-mail: vania.girianelli@ini.fiocruz.br; vaniagirianelli@yahoo.com.br).
\end{abstract}

\begin{abstract}
Keywords

- uterine cervical neoplasm

- prevention and control

- mass screening

- papanicolaou

- HPV

- cohort study

Purpose To compare the predictive capability of HPV and Pap smear tests for screening pre-cancerous lesions of the cervix over a three-year follow-up, in a population of users of the Brazilian National Health System (SUS).

Methods This is a retrospective cohort study of 2,032 women with satisfactory results for Pap smear and HPV tests using second-generation hybrid capture, made in a previous study. We followed them for 36 months with data obtained from medical records, the Cervix Cancer Information System (SISCOLO), and the Mortality Information System (SIM). The outcome was a histological diagnosis of cervical intraepithelial neoplasia grade 2 or more advanced lesions (CIN2+). We constructed progression curves of the baseline test results for the period, using the Kaplan-Meier method, and estimated sensitivity, specificity, positive and negative predictive value, and positive and negative likelihood ratios for each test.

Results A total of 1,440 women had at least one test during follow-up. Progression curves of the baseline test results indicated differences in capability to detect CIN2+ $(p<0.001)$ with significantly greater capability when both tests were abnormal, followed by only a positive HPV test. The HPV test was more sensitive than the Pap smear ( $88.7 \%$ and $73.6 \%$, respectively; $p<0.05)$ and had a better negative likelihood ratio $(0.13$ and 0.30 , respectively). Specificity and positive likelihood ratio of the tests were similar.

Conclusions These findings corroborate the importance of HPV test as a primary cervical cancer screening.
\end{abstract}

received

October 27, 2015

accepted

December 2, 2015

published online

March 21, 2016
DOI http://dx.doi.org/

10.1055/s-0036-1580712. ISSN 0100-7203.
Copyright $\odot 2016$ by Thieme Publicações License terms

Ltda, Rio de Janeiro, Brazil 


\section{Resumo}

\section{Palavras-chave}

- neoplasias do colo do útero

- prevenção e controle

- programas de rastreamento

- Papanicolau

- HPV

- estudo de coorte
Objetivo Comparar a capacidade preditiva do teste HPV com o exame de Papanicolau para a detecção de lesões precursoras do câncer do colo do útero, em três anos de seguimento, numa população de usuárias do Sistema Único de Saúde (SUS).

Métodos Estudo de coorte retrospectiva de 2.032 mulheres com resultados satisfatórios para exame de Papanicolaou e teste HPV, por captura híbrida de segunda geração, realizados em estudo prévio. Foi realizado seguimento durante 36 meses por meio da busca em prontuários, Sistema de Informação do Câncer do Colo do Útero (SISCOLO) e Sistema de Informação sobre Mortalidade (SIM). O desfecho foi o diagnóstico histopatológico de neoplasia intraepitelial cervical grau 2 ou lesão mais grave (NIC2+). Curvas de progressão foram construídas, para o período, utilizando o método de Kaplan-Meier, com base nos resultados dos exames na entrada do estudo; e estimadas a sensibilidade, especificidade, valor preditivo positivo e negativo, e a razão de verossimilhança positiva e negativa, para cada teste.

Resultados Um total de 1.440 mulheres foram submetidas a pelo menos um exame no período de seguimento. As curvas de progressão demonstraram diferenças na capacidade de predição para NIC2 + conforme os resultados dos testes $(p<0,001)$, sendo expressivamente maior quando ambos os exames estavam alterados, seguido de ter apenas o teste HPV positivo. O teste HPV apresentou maior sensibilidade do que o exame de Papanicolau $(88,7 \%$ e $73,6 \%$, respectivamente; $p<0,05)$ e melhor razão de verossimilhança negativa $(0,13$ e 0,30 , respectivamente). Já a especificidade e a razão de verossimilhança positiva foram semelhantes.

Conclusões Os resultados sinalizam a importância da inclusão do teste HPV no rastreamento primário do câncer do colo do útero.

\section{Introduction}

Several studies have sought to evaluate the screening accuracy of HPV detection tests, after the recognition that infection by high oncogenic risk types is required for the development of cervical cancer. ${ }^{1,2}$ A meta-analysis comparing the HPV detection test with the cytological examination ${ }^{3}$ found that the HPV test was more sensitive in detecting cervical intraepithelial neoplasia grade 2 or higher (CIN2+). The specificity, however, was lower, even in women over 30 years old, where HPV infection tends to be less frequent.

Recently, a systematic review of randomized studies that evaluated the HPV detection test in the screening of cervical cancer was performed. ${ }^{4}$ Six studies were included in the analysis, although there were differences regarding the type of cytological exam and HPV detection used, eligibility criterion, and forwarding for colposcopy. Despite the methodological differences, the authors concluded that, after two rounds of screening, the HPV test was more sensitive than the cytological examination for the detection of cervical intraepithelial neoplasia grade 3 or higher, but only when a positive HPV test was used as a criterion for immediate referral to colposcopy, even with normal cytological examination. None of the studies, however, resembled the followup strategy recommended by the Brazilian program for the prevention of cervical cancer. $^{5}$

The main barrier to the success of screening with conventional cytology is the difficulty of access to carry out exami- nations and treatment. This barrier, however, generally does not occur for women participating in clinical studies. In a study conducted in India, ${ }^{6}$ for example, the control group received only guidance about the places that performed the Pap smear, without guaranteeing it. After eight years of follow-up, the authors observed that screening with the HPV test provided a statistically significant protection against death by cervical cancer and diagnosis of the disease with advanced staging. The results, however, were similar when compared with the intervention group submitted only to the Pap test.

The objective of this study was to compare the predictive capacity of the HPV test with the Pap test in detecting precursor cervical cancer lesions, in a population of users of the Unified Health System (SUS).

\section{Methods}

\section{Study Design and Sample Population}

This was a retrospective cohort study, using the existing records of the results of cytological, colposcopic, and histopathological tests from 2002 to 2006. These data were extracted from the Cervix Cancer Information System (Sistema de Informação do Câncer do Colo do Útero -SISCOLO) of the State of Rio de Janeiro and from the medical records of women participating in the study in the health units concerning diagnostic confirmation and treatment. Additionally, death data were obtained from the Mortality Information System (SIM) of the State of Rio de Janeiro. 
In all, 2,032 women were eligible for the study by presenting a satisfactory Pap test and HPV test in a prior examination. ${ }^{7}$ The samples were analyzed by the Integrated Technology Service in Cytopathology (Serviço Integrado de Tecnologia em Citopatologia - SITEC) of the Brazilian National Cancer Institute (INCA). Women for whom at least one exam (Pap, colposcopy, or histopathology) was not present in the sources consulted during the follow-up period were excluded.

\section{Variables Analyzed}

The results of the Pap tests were categorized according to the classification at the time, both upon enrolment in the study, and in the follow up: Negative - without abnormal cells or benign cell changes; and Altered - abnormal epithelial cells, which included: low-grade lesion (cytopathic effect of HPV and Cervical Intraepithelial Neoplasia grade 1), ASCUS (Atypical Squamous Cells of Undetermined Significance), AGUS (Atypical Glandular cells of Undetermined Significance), high-grade lesion (Cervical Intraepithelial Neoplasia (CIN) Grade 2 and 3, invasive squamous cell carcinoma and adenocarcinoma).

The results of the colposcopic evaluation were classified as: negative, unsatisfactory, or positive. The histopathological evaluation was classified as: negative, CIN 1, CIN 2, CIN 3, invasive squamous cell carcinoma, adenocarcinoma in situ, or invasive adenocarcinoma, according to the recommendations of the World Health Organization. ${ }^{8}$

The HPV test used was a second generation hybrid capture method for a cervical-vaginal smear. The results were categorized as positive when the evidence used for high-risk oncogenic types was equal to or higher than the positive control, and negative for the rest.

Age was classified into three categories based on the date of enrollment in the study: 25 to 34 years, 35 to 49 years, and 50 to 59 years.

The outcome of interest was a diagnosis of Cervical Intraepithelial Neoplasia grade 2 or higher (CIN2+) in the histopathological evaluation.

All women included in the study were observed from the date of collection for the Pap and HPV tests, which occurred at the same time. We considered the first diagnosis of CIN2+ in the histopathological evaluation as the criterion of failure. The observation was censored at the date of the last test (Pap test, colposcopy, or histopathology) performed or after 36 months of follow-up.

To evaluate the possibility of selective loss, women who did not complete the follow-up were compared with those with complete follow-up in relation to socioeconomic and demographic characteristics, as well as the results of examinations performed at enrollment (Pap and HPV).

To evaluate the predictive capacity of each test, progression curves for CIN2+ were constructed for the period evaluated, using the Kaplan-Meier method. The curves were stratified considering the results of examinations performed and the age groups at enrollment. The log-rank test was used to compare the curves for each stratum during the follow-up period, and a difference was considered significant when the $\mathrm{p}$ value was less than 0.05 . The sensitivity, specificity, positive and negative predictive value, and the positive (LR+) and negative likelihood ratio (LR-), which describes the performance of the test summarizing the information of sensitivity and specificity, ${ }^{9}$ were also calculated for the follow-up period.

The Chi-square test $\left(\chi^{2}\right)$ was used to compare the proportions evaluated, considering the statistically significant difference when $\mathrm{p}$ value was lower than 0.05 . We performed the analyses using the R statistical program (version 2.5.1).

The research was approved by the Research Ethics Committee of the Brazilian National Cancer Institute (registration number 074/06).

\section{Results}

A total of 1,440 women (70.9\%) had attended at least one exam in the follow-up period evaluated. The study population was similar to the eligible population (2,032 women) regarding the municipality of residence, age group, family income, educational level, and the results of initial tests ( $p>0.05)$. However, a lower proportion of women with both exams negative ( $80.2 \%$ versus $75.1 \% ; p<0.001$ ) was included in the study (data not shown).

Information was obtained in $53.9 \%$ of the population studied until the end of the follow-up period (36 months), and $76.8 \%$ for at least 18 months. - Table 1 presents the socioeconomic and demographic characteristics and the results of initial exams of the study population $(1,440)$ and those with complete follow-up (776). Selective loss was not observed in relation to the variables assessed ( $p>0.05$ ).

Among the women with incomplete follow-up (664), 273 (41.1\%) presented two consecutive negative Pap tests, with a minimum interval of twelve months. In accordance with the recommendations of the Brazilian program, ${ }^{5}$ these women should be examined again only after three years, that is, after the conclusion of the study. Additionally, 184 (27.7\%) women presented with a negative colposcopic or histopathological evaluation in the last exam performed and, in 97 (14.6\%), the last Pap test was negative.

During the follow-up period, four women died, three of them from causes not related to cervical cancer and with a negative initial Pap test, and one by ill-defined and not specified causes who had presented with a high-grade lesion in the initial Pap test and CIN1 in the histopathological evaluation. All presented with a negative HPV test at enrollment.

Fifty-three women were identified with $\mathrm{CIN} 2+$ in the follow up period, and the majority $(67.9 \%)$ presented with altered Pap and HPV tests at enrollment. $20.8 \%$ of the cases had only an altered HPV test, including a single case of adenocarcinoma diagnosed during the period. Three cases with a diagnosis of CIN2, however, had both tests (Pap test and HPV) normal at enrollment (-Table 2 ).

The curves of progression for CIN2+ stratified by age group were overlapped ( $p=0.83$ ), indicating no significant difference in the population studied, during the follow-up period evaluated (data not shown). The curves for the 
Table 1 Characteristics of the participants at the beginning of the study and with complete follow-up

\begin{tabular}{|c|c|c|c|c|c|}
\hline \multirow[t]{2}{*}{ Characteristics } & \multicolumn{2}{|c|}{$\begin{array}{l}\text { Participants at the } \\
\text { beginning of the study } \\
\text { ( } n=1440)\end{array}$} & \multicolumn{2}{|c|}{$\begin{array}{l}\text { Participants with } \\
\text { complete follow-up } \\
(n=776)\end{array}$} & \multirow[t]{2}{*}{$P$ Value $^{\mathrm{b}}$} \\
\hline & $\mathrm{N}$ & $\%^{\mathrm{a}}$ & $\mathrm{N}$ & $\%^{\mathrm{a}}$ & \\
\hline \multicolumn{5}{|l|}{ Municipality of residence } & \multirow[t]{3}{*}{0.572} \\
\hline Duque de Caxias & 701 & 48.7 & 368 & 47.4 & \\
\hline Nova Iguaçu & 739 & 51.3 & 408 & 52.6 & \\
\hline \multicolumn{5}{|l|}{ Age Group } & \multirow[t]{4}{*}{0.664} \\
\hline $25-34$ & 485 & 33.7 & 271 & 34.9 & \\
\hline $35-49$ & 684 & 47.5 & 353 & 45.5 & \\
\hline $50-59$ & 271 & 18.8 & 152 & 19.6 & \\
\hline Years of schooling & 343 & & & & \multirow[t]{5}{*}{0.572} \\
\hline $0-3$ & 664 & 24.0 & 199 & 25.8 & \\
\hline $4-7$ & 425 & 46.4 & 355 & 46.0 & \\
\hline$\geq 8$ & 8 & 29.7 & 217 & 28.1 & \\
\hline Unknown & 0 & - & 5 & - & \\
\hline \multicolumn{5}{|l|}{ Family income } & \multirow[t]{5}{*}{0.591} \\
\hline$<2$ minimum wages & 630 & 45.8 & 388 & 46.9 & \\
\hline 2 to $<5$ minimum wages & 605 & 44.0 & 367 & 44.4 & \\
\hline$\geq 5$ minimum wages & 141 & 10.2 & 74 & 8.7 & \\
\hline Unknown & 64 & - & 44 & - & \\
\hline \multicolumn{5}{|l|}{ Pap test } & \multirow[t]{3}{*}{0.561} \\
\hline Altered & 204 & 14.2 & 117 & 15.1 & \\
\hline Normal & 1236 & 85.8 & 659 & 84.9 & \\
\hline \multicolumn{5}{|l|}{ HPV test } & \multirow[t]{3}{*}{0.192} \\
\hline Positive & 241 & 16.7 & 147 & 18.9 & \\
\hline Negative & 1199 & 83.3 & 629 & 81.1 & \\
\hline
\end{tabular}

aExcluding unknown data.

${ }^{b} \mathrm{p}$ value based on the Chi-square test.

outcome of the initial tests (-Fig. 1), in turn, point to differences in the predictive capacity for CIN2+ according to the results of the tests $(p<0.001)$, being expressively higher when both test results were altered, followed by having only the HPV test positive.
Screening with the HPV test revealed a higher sensitivity than the Pap test ( $88.7 \%$ and $73.6 \%$, respectively; $p<0.05$ ) and a similar specificity (86.0 and 88.1 , respectively; $p=0.10)$. Screening with the tests combined presented similar sensitivity $(94.3 \%, p=0.49)$ and lower specificity

Table 2 Results of the histopathological evaluation of cases diagnosed during follow-up, according to results of Pap and HPV tests upon enrollment in the study

\begin{tabular}{|l|l|l|l|l|l|l|}
\hline \multirow{2}{*}{ Results of Pap and HPV tests } & \multicolumn{3}{|l|}{ Result of the histopathological evaluation } & \multirow{2}{*}{ Total } \\
\cline { 2 - 6 } & CIN 2 & CIN 3 & Carcinoma & Adenocarcinoma & \\
\hline Both altered & 12 & 23 & 1 & - & 1 & 36 \\
\hline Only HPV altered & 3 & 7 & - & - & 11 & 20.8 \\
\hline Only Pap altered & 2 & 1 & - & - & 3 & 5.7 \\
\hline Both negative & 3 & - & - & 1 & 3 & 5.7 \\
\hline Total & 20 & 31 & 1 & 1.9 & 53 & 100.0 \\
\hline$\%$ & 37.7 & 58.5 & 1.9 & 100.0 & - \\
\hline
\end{tabular}




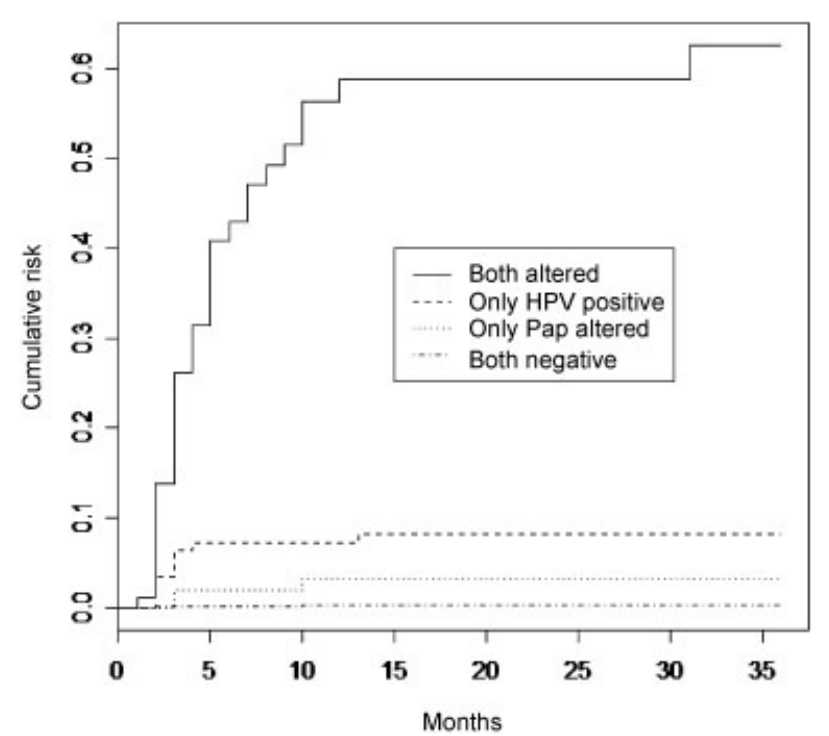

Fig. 1 Curves of progression for CIN2 or higher according to the results of Pap test (Pap) and HPV detection upon enrolment in the study.

(77.8\%, $p<0.001$ ) than the HPV test alone ( - Table 3). The positive predictive value was similar among all tests ( $p>0.05$ ), while the negative predictive value was higher for the combined tests than for the Pap test $(p=0.02)$ and similar to the HPV test $(p=0.61)$.

With regard to the positive and negative likelihood ratio of the tests evaluated, the performance of the HPV test was similar to the Pap test, whose likelihood of detecting CIN2+ among women with an altered test was about 6 -fold higher than in the total population. However, the likelihood of detecting CIN2+ among women with both tests negative (LR- =0.07; IC95\%: 0.02-0.22) or with only the HPV test negative (LR- $=0.13$; IC 95\%: 0.06-0.28) was very low, which was not the case for women with only the negative Pap smear test (LR- =0.30; CI 95\%: 0.13-0.47).

\section{Discussion}

In this study, only women who submitted to at least one exam in the follow-up period were included, resulting in a lower proportion of women with both initial exams negative than the reference population. Consequently, the population included probably had a greater likelihood of detecting CIN2+, suggesting that the estimates obtained may be overestimated. However, as there was no selective loss of followup, we expect the estimates to be comparable between the tests evaluated.

Screening with the HPV test presented a similar performance to the Pap test for detection of $\mathrm{CIN} 2+$, with a positive likelihood ratio of around 6 . However, the sensitivity of the HPV test was higher and having a negative HPV test provided a smaller likelihood (LR-) of detection of CIN2 + than having a negative Pap test, at three years of follow-up. The use of these tests combined did not present a better performance than the HPV test alone.

In a randomized study conducted in Sweden, ${ }^{10}$ the researchers used the Pap test and PCR for identification of HPV in the two arms of the study, but with the result of the PCR revealed only in the intervention group. However, after three years of follow-up, it was necessary to apply the same referral protocol for diagnostic confirmation in the control group because the proportion of HPV positive women with diagnosis of $\mathrm{CIN} 2+$ in the intervention group was greater than that expected.

In contrast, in a non-randomized study conducted in the United States, ${ }^{11}$ with ten-year follow-up, the authors observed initially a higher risk of detection of CIN3+ associated with positivity on the Pap test compared with positivity on the HPV test. This occurred particularly in the first nine months, but the differences between the estimates

Table 3 Comparison of the Pap and HPV tests in detecting CIN2 or more serious lesions

\begin{tabular}{|c|c|c|c|c|c|c|c|c|}
\hline \multirow[t]{2}{*}{ Tests } & \multicolumn{2}{|c|}{ Sensitivity } & \multicolumn{2}{|c|}{ Specificity } & \multicolumn{2}{|c|}{$\begin{array}{l}\text { Positive Predic- } \\
\text { tive value }\end{array}$} & \multicolumn{2}{|c|}{$\begin{array}{l}\text { Negative Predic- } \\
\text { tive value }\end{array}$} \\
\hline & $\%$ & $\mathrm{p}^{\mathrm{a}}$ & $\%$ & $\mathrm{p}^{\mathrm{a}}$ & $\%$ & $\mathrm{p}^{\mathrm{a}}$ & $\%$ & $\mathrm{p}^{\mathrm{a}}$ \\
\hline HPV & 88.7 & 0.047 & 86.0 & 0.101 & 19.5 & 0.919 & 99.5 & 0.084 \\
\hline versus & - & & - & & - & & - & \\
\hline Pap & 73.6 & & 88.1 & & 19.1 & & 98.9 & \\
\hline HPV and/or Pap & 94.3 & 0.004 & 77.8 & $<0.001$ & 14.0 & 0.108 & 99.7 & 0.016 \\
\hline versus & - & & - & & - & & - & \\
\hline Pap & 73.6 & & 88.1 & & 19.1 & & 98.9 & \\
\hline HPV and/or Pap & 94.3 & 0.486 & 77.8 & $<0.001$ & 14.0 & 0.071 & 99.7 & 0.607 \\
\hline versus & - & & - & & - & & - & \\
\hline HPV & 88.7 & & 86.0 & & 19.5 & & 99.5 & \\
\hline
\end{tabular}

${ }^{a} \mathrm{p}$ value based on the Chi-square test. 
decreased over the follow-up. For this study, however, cervical-vaginal washing was initially used to test for HPV, likely a less sensitive harvesting technique than the direct harvest of exfoliated cells of the uterine cervix. In addition, the results of the HPV test were not used as a criterion for the referral for diagnostic confirmation, which may have delayed the diagnosis of women with HPV infection and negative Pap test. In the present study, $31.8 \%$ of the women who presented with only a positive HPV test underwent histopathological evaluation. This may have favored earlier detection and precluded to assess whether the Pap smear could identify precursor lesions in subsequent screenings. However, the recent results of the American study cited above ${ }^{12}$ signaled that the inclusion of only the HPV test would be enough for the primary screening of cervical cancer. Additionally, in a recent review performed on the prediction of CIN2+ in screening for minor cervicalvaginal lesions ${ }^{13}$ (ASCUS and low-grade lesion), the authors observed that the HPV test presented higher sensitivity than repetition with cytological test, but lower specificity in the triage of low grade lesions, however, with greater heterogeneity among the studies in relation to the results of the cytological test.

In a study conducted in Italy, ${ }^{14}$ screening with the HPV test was more sensitive in detecting $\mathrm{CIN} 2+$, in particular for younger women ( $<35$ years). The authors concluded that these findings could represent an over-diagnosis of lesions that would regress. In the present study, around 20\% of women with CIN2+ had positive HPV and negative Pap results, half of them with more than 34 years of age. Therefore, it is possible that a portion of these lesions could progress, and women with greater difficulty of access to screening and health services could be diagnosed later, implying a worse clinical outcome.

In this study, the difference in sensitivity of the HPV and Pap tests (88.7 and $73.6 \%$, respectively) was significant, although the Pap test performed upon enrollment was analyzed in a reference laboratory (SITEC) with proven quality, which increases the probability of approaching the maximum sensitivity expected for this test. However, this difference could be even higher if all Pap tests were performed in different laboratories given that sensitivity values below $31 \%$ have already been described in the country. ${ }^{15-17}$ Additionally, the Pap test presents a low capacity to detect adenocarcinomas which represent around $10 \%$ of cervical cancers. $^{18}$

Although the results suggest that the HPV test can have an advantage compared with the reference test used in the country, its application depends on multiple logistic and technical issues for which the diagnostic capacity of most municipalities is still not ready. The incorporation of the test in the long term can have a cost benefit, but the cost of the initial deployment is high because the public laboratories and contractors of SUS need to be equipped to perform the test.

One can conclude that the HPV test should be considered in the primary screening of cervical cancer at least once in life, in particular for women with greater difficulty of access to health services. However, additional studies should be conducted in a routine context and with a greater follow-up period to evaluate its efficacy in the prevention of cervical cancer, and the consequent cost of the process. One should also assess the technical, welfare, and social implications of the diagnosis of HPV infection, a sexually transmissible disease, in the screening of cervical cancer.

\section{Note}

Research funded by the Conselho Nacional de Desenvolvimento Científico e Tecnologia (CNPq - N 476941/20067; Universal Edit).

\section{References}

1 Franco EL, Rohan TE, Villa LL. Epidemiologic evidence and human papillomavirus infection as a necessary cause of cervical cancer. J Natl Cancer Inst 1999;91(6):506-511

2 Bosch FX, Lorincz A, Muñoz N, Meijer CJ, Shah KV. The causal relation between human papillomavirus and cervical cancer. J ClinPathol 2002;55(4):244-265

3 Koliopoulos G, Arbyn M, Martin-Hirsch P, Kyrgiou M, Prendiville W, Paraskevaidis E. Diagnostic accuracy of human papillomavirus testing in primary cervical screening: a systematic review and meta-analysis of non-randomized studies. GynecolOncol 2007; 104(1):232-246

4 Patanwala IY, Bauer HM, Miyamoto J, Park IU, Huchko MJ, SmithMcCune KK. A systematic review of randomized trials assessing human papillomavirus testing in cervical cancer screening. Am J ObstetGynecol 2013;208(5):343-353

5 Stormo AR, de Moura L, Saraiya M. Cervical cancer-related knowledge, attitudes, and practices of health professionals working in brazil's network of primary care units. Oncologist 2014;19(4): 375-382

6 Sankaranarayanan R, Nene BM, Shastri SS, et al. HPV screening for cervical cancer in rural India. N Engl J Med 2009;360(14): 1385-1394

7 Girianelli VR, Thuler LCS, e Silva GA. [Prevalence of HPV infection among women covered by the family health program in the Baixada Fluminense, Rio de Janeiro, Brazil]. Rev Bras GinecolObstet 2010;32(1):39-46Portuguese

8 Tavassoli FA, Devilee P. Pathology and genetics of tumours of the breast and female genital organs. Lyon: IARC Press; 2003. (World Health Organization Classification of Tumors)

9 Eusebi P. Diagnostic accuracy measures. Cerebrovasc Dis 2013; 36(4):267-272

10 Naucler P, Ryd W, Törnberg S, et al. Human papillomavirus and Papanicolaou tests to screen for cervical cancer. N Engl J Med 2007;357(16):1589-1597

11 Sherman ME, Lorincz AT, Scott DR, et al. Baseline cytology, human papillomavirus testing, and risk for cervical neoplasia: a 10-year cohort analysis. J Natl Cancer Inst 2003;95(1):46-52

12 Katki HA, Kinney WK, Fetterman B, et al. Cervical cancer risk for women undergoing concurrent testing for human papillomavirus and cervical cytology: a population-based study in routine clinical practice. Lancet Oncol 2011;12(7):663-672

13 Arbyn M, Roelens J, Simoens C, et al. Human papillomavirus testing versus repeat cytology for triage of minor cytological cervical lesions. Cochrane Database Syst Rev 2013;3: CD008054

14 Ronco G, Giorgi-Rossi P, Carozzi F, et al; New Technologies for Cervical Cancer screening (NTCC) Working Group. Efficacy of human papillomavirus testing for the detection of invasive 
cervical cancers and cervical intraepithelial neoplasia: a randomised controlled trial. Lancet Oncol 2010;11(3):249-257

15 Cordeiro MRA, Costa HLFF, Andrade RP, Brandão VRA, Santana R. [Cervical visual inspection after application of acetic acid in screening intraepithelial neoplasia and HPV-induced lesions]. Rev Bras GinecolObstet 2005;27(2):51-57Portuguese

16 Rios SS. [Intra-epithelial cervical lesions: diagnosis using cervical test and colposcopy associated with cervical biopsies]. RevBrasGinecolObstet 2004;26(10):818Portuguese
17 Veras TMCW, Holanda Junior F, Lins MZ, et al. Efetividade da captura híbrida para HPV no rastreamento primário de lesões cervicais na rotina de serviços de saúde. DST J Bras Doenças Sex Transm. 2006;18(1):23-29

18 Nogueira-Rodrigues A, Ferreira CG, Bergmann A, de Aguiar SS, Thuler LC. Comparison of adenocarcinoma (ACA) and squamous cell carcinoma (SCC) of the uterine cervix in a sub-optimally screened cohort: a population-based epidemiologic study of 51,842 women in Brazil. GynecolOncol 2014;135(2):292-296 